\author{
U.S. GEOLOGICAL SURVEY
}

\title{
GEOLOGIC SETTING OF THE YUCAIPA QUADRANGLE, SAN BERNARDINO AND RIVERSIDE COUNTIES, CALIFORNIA
}

\section{SUMMARY PAMPHLET TO ACCOMPANY GEOLOGIC MAP OF THE YUCAIPA QUADRANGLE}

B y

Jonathan C. Matti ${ }^{1}$, Douglas M. Morton ${ }^{2}$, Brett F. Cox ${ }^{3}$, Scott E. Carson ${ }^{4}$, and Thomas J. Yetter 5

\section{OPEN-FILE REPORT 92-446}

This report is preliminary and has not been reviewed for conformity with U.S. Geological Survey editorial standards or with the North American Stratigraphic Code. Any use of trade, product, or firm names is for descriptive purposes only and does not imply endorsement by the U.S. Government.

${ }^{1}$ U.S. Geological Survey Department of Geosciences Gould-Simpson Building University of Arizona Tucson, Arizona 85721

${ }^{4}$ Carson Consultants, Capitola, California
${ }^{2}$ U.S. Geological Survey Department of Earth Sciences University of California Riverside, California 92521
${ }^{3}$ U.S. Geological Survey 345 Middlefield Road, MS 975 Menlo Park, California 94025 


\section{ONTRODUCTION}

The Yucaipa 7.5' quadrangle contains geologic materials and structures that provide unique insight into the Mesozoic and Cenozoic geologic evolution of southern California. These elements include: (1) strands of the San Andreas fault that bound far-travelled terranes of crystalline and sedimentary rock; (2) Mesozoic crystalline rocks that form lower and upper plates of the regionwide VincentOrocopia thrust system; and (3) late Tertiary and Quaternary sedimentary rocks and geologic structures that record complex geologic interactions within the San Andreas fault system. We describe the geologic setting of these and other geologic elements in relation to strands of the San Andreas fault.

Four strands of the San Andreas fault traverse the Yucaipa quadrangle and separate different packages of crystalline and sedimentary rock. From northeast to southwest these faults include (Matti and others, 1992): (1) the Mill Creek strand that traverses Mill Creek and Warm Springs Canyons; (2) the Wilson Creek strand that traverses Yucaipa Ridge and converges toward the Mill Creek strand in Santa Ana River Canyon; (3) the Mission Creek strand inferred to lie along the southwestern base of the San Bernardino Mountains (Matti and others 1985); and (4) the San Bernardino strand that defines the youthful trace of the San Andreas fault in the Yucaipa quadrangle and elsewhere along the southwest margin of the San Bernardino Mountains. All of these strike-slip faults have generated right-lateral displacements of a few to many tens of kilometers.

\section{圆DROCK UNOTS}

\section{ROCKS EAST OF THE WILSON CREEK AND MILL CREEK STRANDS, SAN ANDREAS FAULT}

Rocks east of the Mill Creek strand.--Only one bedrock unit occurs east of the San Andreas fault zone in the Yucaipa quadrangle: coarsely crystalline hornblende monzogranite and quartz monzonite (unit Trm) that is distinguished by large euhedral potassium-feldspar phenocrysts (Frizzell and others, 1986, fig. 2-4). This rock is Triassic in age and is about $215 \mathrm{~m}$.y. old, the oldest rock known from the Yucaipa quadrangle. Its Triassic age is significant because plutonic rocks of this age are not common in southern California, although they occur locally in parts of the San Gabriel and San Bernardino Mountains and in the Mojave and Sonoran Desert provinces. Rocks of Triassic age are important because they record the earliest episode of Mesozoic plutonism that was so voluminous in the southern California region. Some of the Triassic granitoids, like those studied by C.F. Miller (1977, 1978) in the north-central San Bernardino Mountains, have unique alkalic chemistries that provide important clues about how early Mesozoic plutonism in southern California differed from later Mesozoic episodes that were more calc-alkalic in composition. Triassic granitoid rocks of unit Trm in the Yucaipa quadrangle provide another piece of this puzzle, and are significant because their calc-alkalic composition (Frizzell and others, 1986) contrasts with alkalic rocks of comparable age nearby in the San Bernardino Mountains (C.F. Miller, 1977, 1978).

Rocks between the Mill Creek and Wilson Creek strands.--Two bedrock units occur between the Mill
Creek and Wilson Creek strands of the San Andreas: a faultbounded slice of granodioritic rock we term the orthogneiss of Alger Creek (unit Mzga) and nonmarine sedimentary rocks we term the Formation of Warm Springs Canyon (unit Tw). The orthogneiss unit is similar to rocks on the east side of the Mill Creek fault in the Alger Creek area of the adjacent Forest Falls quadrangle, and is part of the evidence cited by Matti and others $(1985,1992)$ for no more than 8 to $10 \mathrm{~km}$ of rightlateral displacement on the Mill Creek strand of the San Andreas. The Warm Springs Canyon Formation is a poorly exposed sequence of nonmarine sandstone and conglomerate whose internal stratigraphy is disrupted by faults and whose east and west boundaries are strands of the San Andreas. No age has been determined for the succession, but lithologic comparison with other nonmarine sedimentary rock sequences in the region suggests that unit $\mathrm{Tw}$ probably is late Miocene in age. If crystalline-rock evidence for no more than $10 \mathrm{~km}$ of right-slip on the Mill Creek strand of the San Andreas is correct, then the Warms Springs Canyon Formation was deposited on crystalline rocks of San Bernardino Mountains type in the Mill Creek region (but see alternative proposals by Sadler and Demirer, 1986, and Hillenbrand, 1990).

\section{THE WILSON CREEK BLOCK: AN EXOTIC SLICE BETWEEN STRANDS OF THE SAN ANDREAS FAULT ZONE}

The Wilson Creek block (Matti and others, 1985, 1992) is a fault-bounded slice of crystalline rocks and overlying nonmarine sedimentary rocks that occurs between the Wilson Creek strand and the San Bernardino and Mission Creek strands of the San Andreas fault. The crystalline rocks are a heterogeneous suite of gneissose, foliated, and texturally massive granitoid rocks that represent a deformed plutonic complex (units Mzgg, Mzc, Mzgr, and Mzg). These rocks are highly fractured locally, especially in the west part of the Yucaipa quadrangle. Crystalline rocks of the Wilson Creek block are dissimilar to crystalline rocks east of the Wilson Creek fault, and they are not native to the San Bernardino Mountains. The Wilson Creek block is generally similar to rocks in the northern Little San Bernardino Mountains, from which the block probably has been displaced by movements on the Wilson Creek and Mill Creek faults (Matti and Morton, 1992).

The crystalline complex is overlain depositionally by nonmarine sedimentary rocks of the Mill Creek Formation of Gibson $(1964,1971)$. Woodburne (1975) reviewed permissive evidence supporting a late Miocene age for the unit, but its age is not well established. The formation (unit Tm) consists of mudstone, sandstone, and conglomerate deposited in alluvial-fan, riverine, and lacustrine settings. Steep slopes underlain by the Mill Creek Formation are prone to failure, particularly where mudrock is interlayered with sandstone and conglomerate, and the formation is marked by numerous small and large landslides. Youthful and older landslides are particularly prominent west and east of State Route 38 in Mill Creek Canyon and along the southwest base of Yucaipa Ridge east of the mouth of Mill Creek.

Stratigraphic relations between the Mill Creek Formation and the Warm Springs Canyon Formation east of the Wilson Creek fault are problematical, and are interpreted in different ways by different workers. Most investigators sug gest a stratigraphic and paleogeographic link between the two units. For example, Dibblee (1982, fig. 7) grouped the two 
units together within the Mill Creek Formation, and implied that they were deposited together elsewhere in southern California before being displaced jointly into the Mill Creek region by his north branch of the San Andreas fault (the Mill Creek strand of our usage). Demirer (1985), Sadler and Demirer (1986), and West (1987) elaborated this concept by proposing that the two sedimentary sequences are halves of a two-sided depositional basin that developed within a rift zone of the ancient San Andreas fault. Despite the conclusions of these earlier studies, we maintain that sedimentary rocks we assign to the Mill Creek and Warm Springs Formations are two distinct and different sequences separated by the Wilson Creek fault. We acknowledge lithologic similarities between them, but we emphasize three points that in our judgment warrant separation of the two units: (1) the Warm Springs Canyon Formation is a sequence that overall is compositionally and texturally more immature than the Mill Creek Formation; (2) the geometry and pattern of sedimentary facies in the Mill Creek Formation is far more orderly than in the Warm Springs Canyon Formation; and (3) we have not observed the two sequences to interfinger with each other as indicated by Demirer (1985) and West (1987).

\section{ROCKS WEST OF THE SAN ANDREAS FAULT}

Mesozoic crystalline rocks.--Southwest of the San Bernardino and Mission Creek strands of the San Andreas fault, Mesozoic crystalline rocks in the Yucaipa quadrangle consist of two suites separated by a low-angle thrust fault. Lower-plate rocks of this thrust are metamorphosed Mesozoic sedimentary rocks assigned to the Pelona Schist (unit ps 1 ). The schist represents quartzofeldspathic marine sedimentary rocks that have been metamorphosed to greenshist grade, presumably at the same time as they were overthrust by the upper-plate rocks. Upper-plate rocks consists of strongly foliated Mesozoic granitoid rocks (units Mzmg and $\mathrm{Mzfg}$ ) that mainly are granodioritic and tonalitic in composition; this terrane includes small bodies of granodioritic and monzogranitic rock lithologically similar to the Triassic Mount Lowe plutonic complex of the San Gabriel Mountains (described by Joseph and others, 1982 and Barth and Ehlig, 1988). These small bodies are remnants of a formerly widespread Triassic plutonic suite that subsequently was intruded and enveloped by younger Mesozoic granitoids. Much of the upper-plate rock has mylonitic and cataclastic fabrics that were created when the rock was deformed by ductile and brittle-ductile shearing and squeezing; these fabrics are most pronounced near the thrust fault separating upper and lower plates, and presumably were developed when the two plates were thrust together. These structural relations are similar to those in the southeastem San Gabriel Mountains, where the Vincent thrust separates Pelona Schist in the lower plate from various deformed granitoid rocks in the upper plate (Ehlig, 1981; Morton, 1975). We follow most workers who extend the name "Vincent thrust" to the Crafton Hills area of the Yucaipa quadrangle (Ehlig, 1968, 1981, 1982; Dibblee, 1968, 1975, 1982; Matti and others, 1985, 1992).

Cenozoic rocks.--Cenozoic geologic units west of the San Andreas fault include middle(?) Tertiary igneous rocks and upper Tertiary and Quaternary sedimentary rocks of the San Timoteo Formation. The igneous rocks occur in the upper and lower plates of the Vincent thrust. One of these (unit Tgr) is qranodiorite and quartz-porphyry dikes that intrude Pelona Schist in the Crafton Hills and north of Mill
Creek near Mentone; the other (unit Ta) is andesitic to dacitic dikes that intrude the upper plate of the Vincent thrust in the hills on the east margin of the Yucaipa quadrangle. We infer that these two igneous rock units are mid Tertiary in age (Miocene and [or] Oligocene) based on their lithologic similarity to rocks of that age identified in the lower and upper plates of the Vincent thrust elsewhere in southern California.

The major Cenozoic rock unit west of the San Andreas fault in the Yucaipa quadrangle is the Formation of San Timoteo Canyon (unit QTst). Throughout its outcrop belt in the San Timoteo Badlands the unit ranges from early Pliocene through late Quaternary in age, but in the Yucaipa quadrangle only the late Quaternary part of the Formation is exposed. These sediments represent flood-plain and alluvialfan deposits that were deposited from streams flowing southwest between the crystalline Crafton Hills and the crystalline hills east of Yucaipa and Calimesa.

\section{QUATERNARY SURFICHAL

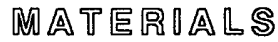

Surficial materials of Quaternary age occur throughout the Yucaipa quadrangle. Within the San Bernardino Mountains, mappable bodies of colluvium (unit Qc) mantle some hillslopes. Canyon bottoms are veneered with deposits of active streamflows (units $\mathrm{Qw}$ and $\mathrm{Qa}$ ) and flanked by older deposits of streams and alluvial fans (various units of Qya and Qoa and Qyf and Qof) that form step-like terraces rising above the active washes. Landslides occur throughout the mountain region, but are most abundant on hillslopes underlain by the Mill Creek Formation. The landslides include both loose cohesionless masses of rubble and intact blocks of bedrock that have slumped downhill. Some landslides are active, like those along the west side of State Route 38 near the mouth of Mill Creek Canyon; other slides are older and inactive under current climatic and tectonic conditions. All landslides are susceptible to reactivation under severe earthquake-generated groundshaking conditions or high-rainfall conditions.

In lowlands west of the San Andreas fault zone, Quatemary surficial materials are extensive. There, we differentiate between alluvial-plain materials deposited in lowlands by valley-following rivers and streams (units $Q w, Q a, Q y a$, Qoa, and Qvoa) and alluvial-fan materials deposited in coneshaped aprons that flank the margins of hills and mountains or that build down onto throughgoing valley plains from lateral tributaries (units Qf, Qyf, Qof, and Qvof). This distinction primarily is genetic: although alluvial-fan deposits typically are coarser grained and more poorly sorted than texturally and compositionally more mature alluvial-plain deposits, the physical properties (consolidation, permeability, soil-profile development) of coeval alluvial-fan and alluvial-plain deposits generally are comparable.

Quaternary deposition west of the San Andreas fault has occurred in three cycles:

Very old deposits (Qvoa, Qvof).--These occur in two main areas: flanking the San Bernardino strand of the San Andreas fault between Mill Creek and Santa Ana River, and on the southwest part the Crafton Hills Horst. Both deposits are characterized by pedogenic soil profiles having very red $B$ horizons as thick as 2 to $3 \mathrm{~m}$. Soils of this maturity are comparable to soil-stage S2 of McFadden (1982), and are about 500,000 years old. 
Deposits flanking the San Andreas fault consist of sand-and-gravel deposits (unit Qvof ${ }_{1}$ ) that have been tilted as steeply as $65^{\circ}$ toward the San Bernardino Valley. These deposits contain cobbles and boulders derived from bedrock units east of the San Bernardino strand, including the Mill Creek Formation, units Trm and Mzga, and various crystalline rock units that crop out in the Mill Creek drainage beyond the borders of the Yucaipa quadrangle. Unit Qvof ${ }_{1}$ here represents alluvial-fan deposits that originally accumulated at the canyon mouth of Mill Creek and since have been displaced rightlaterally about 2 to $3 \mathrm{~km}$ by the San Bernardino strand of the San Andreas fault.

Deposits on the Crafton Hills horst consist of sand and gravel and interlayered paleosols (unit Qvoa 1 ) that rest depositionally on top of the San Timoteo Formation. This unit apparently evolved as the southwest-dipping basinal gradient of the San Timoteo Formation was disrupted and replaced by west- to northwest-dipping gradients that included elevated areas of weathering and regolith development as well as areas of alluvial-plain deposition. Paleogeographic relations involving unit Qvoa 1 and older and younger units are complex: in the Smiley Heights area north of Live Oak Canyon, deposition of Qoa 1 apparently was followed soon by erosion and soil-profile development; in the Sand Canyon area to the east, deposition of Qoa 1 apparently continued intermittently while the Smiley Heights area was undergoing erosion and regolith development. These inferences are based on the greater degree of soil-profile development in the Smiley Heights area and the more integrated longitudinal erosion patterns there in comparison with the Sand Canyon area.

Old deposits (Qoa, Qof).--These occur at various places west of the $S$ an Andreas fault. The deposits are characterized by pedogenic soil profiles having very red $\mathbf{B}$ horizons as thick as 0.5 to $2 \mathrm{~m}$; soils of this maturity are comparable to soil-stages S3, S4, and S5 of McFadden (1982), and are between 500,000 and 50,000 years old.

Interfingering relations between units of Qoa and Qof in the Yucaipa Valley area provide insight into the interplay between sedimentation and tectonics. Units of Qoa are valley-filling deposits laid down by throughgoing streamflows of ancestral Oak Glen and Yucaipa Creeks; these streams ultimately flowed down ancestral Live Oak Canyon to meet San Timoteo Creek. They were confined to this paleo-drainage pattern by the high-standing Crafton Hills horst that, by this time, had been uplifted to form a barrier to paleogeographic connection between the Yucaipa Valley area and the San Bernardino Valley to the northwest. During this same time period, the stream valley of ancestral Oak Glen Creek was flanked along its north margin by alluvial fans that emanated from canyons heading north into Yucaipa Ridge. This paleogeographic configuration led to different cobble populations for the two different depositional regimes: (1) valley-filling deposits of Qoa that accumulated in ancestral Oak Glen Valley have clasts derived mainly from crystalline bedrock units of Yucaipa Ridge east of the Yucaipa quadrangle; (2) alluvial-fan deposits flanking Yucaipa Ridge in the map area have clasts derived mainly from the Mill Creek Formation. These differences in clast populations is the main basis for distinguishing units of Qoa from units of Qof in the northern Yucaipa Valley area, and were used by Harden and Matti (1989) to estimate slip rates for the San Bernardino strand of the San Andreas fault (discussed below).

Young deposits (Qya, Qyf).--These sand-andgravel deposits are characterized by pedogenic soil profiles having minimal soil-profile development: the $A / C_{o x} / C$ profiles are no thicker than 1 or $2 \mathrm{~m}$, with the maturest profiles having $\mathbf{B}_{\text {cambic }}$ horizons that lack illuvial clay. These soils are Holocene to latest Pleistocene in age, coincide with soilstages S6 and S7 of McFadden (1982), and are between 15,000 and 500 or 1,000 years old.

Younger surfical deposits in the Yucaipa quadrangle are not so widespread as old and very old surficial deposits This distribution pattern reflects a major contrast between paleogeographic settings for older Quaternary and latest Quatemary deposits: old and very old Quaternary units resulted from major aggradational pulses that distributed sediment across a landscape that was relatively smooth, whereas young Quaternary units have resulted from minor aggradational pulses that deposited sediment locally on a landscape that is tectonically active and that mainly is undergoing erosional dissection. The young deposits also are more susceptible to local base-level influences than were older deposits. For example, several local areas of young alluviation occur adjacent to fault scarps of the Yucaipa Valley graben complex, and are accumulating on down-thrown blocks while sediment is being eroded from up-thrown blocks. These tectonic influences on sedimentation patterns for the last 15,000 years or so allow us to interpret the recency of faulting in the Yucaipa quadrangle.

STRUCTURAR GEOLOGY

\section{SAN ANDREAS FAULT ZONE}

The San Andreas fault zone is the most conspicuous structural element in the Yucaipa quadrangle, and is of interest because of its potential for generating large earthquakes. We examine briefly here the geology of the four strands recognized by Matti and others $(1985,1992)$.

Mill Creek strand: From southeast to northwest, the Mill Creek strand traverses Mill Creek and Warm Springs Canyons and crosses Santa Ana River Canyon before exiting the Yucaipa quadrangle. Throughout much of its extent the fault is concealed beneath young Quaternary alluvium and colluvium, but where it traverses bedrock the fault forms a zone of sheared and crushed rock as much as $10 \mathrm{~m}$ wide.

Most workers agree that the Mill Creek fault is a right-lateral strike-slip strand of the San Andreas fault zone, but disagreement exists regarding its tectonic significance. Early workers interpreted the fault as a major San Andreas strand having right-slip displacements in excess of $100 \mathrm{~km}$. This interpretation stems from Gibson's work in the Yucaipa quadrangle, where he (Gibson, 1964) studied the Mill Creek Formation and concluded that these sedimentary rocks originally were deposited in the vicinity of the Orocopia Mountains northeast of the Salton Sea; following their deposition, these rocks were displaced into the vicinity of the Yucaipa quadrangle by $120 \mathrm{~km}$ of right slip on the Mill Creek fault (Gibson, 1964, 1971). Dibblee (1968, p. 269) concluded that, if strands of the San Andreas fault in the southeastern San Bernardino Mountains have contributed to the $210 \mathrm{~km}$ of right-slip proposed for the San Andreas in southern California by Crowell (1962), then the largest movement probably occurred along the Mill Creek fault (his north branch of the San Andreas). Later, Dibblee (1975, p. 134) proposed that his north branch generated about $96 \mathrm{~km}$ of right slip and displaced crystalline rocks in the southeastern San Bemardino 
Mountains from unspecified counterparts in the Orocopia Mountains. Dibblee (1982, p. 164) subsequently increased this value to $120 \mathrm{~km}$--a displacement identical to Gibson's $(1964,1971)$ and presumably based on Gibson's palinspastic restoration of the Mill Creek Formation to the Orocopia Mountains region. Sadler and Demirer (1986) used paleogeographic reconstructions for the Mill Creek Formation to conclude that the Mill Creek fault has displaced the formation from a depositional position between the Little San Bernardino and Orocopia Mountains--a distance of more than $110 \mathrm{~km}$. Most recently, Hillenbrand (1990) proposed that the Mill Creek fault has displaced the Warm Springs Canyon Formation about $40 \mathrm{~km}$ from a presumed cross-fault source for diorite-gabbro clasts that occur in conglomerate beds of the unit.

Other workers view the Mill Creek fault as a minor strand of the San Andreas based on geologic relations immediately east of the Yucaipa Quadrangle. There, Farley (1979) and Matti and others $(1983,1985)$ showed that crystalline rocks directly outboard (west) of the Mill Creek fault are similar to those directly inboard (east) of the fault. We have observed similar relations in the Yucaipa quadrangle where unit Mzga--a foliated orthogneiss outboard of the Mill Creek strand--is lithologically similar to rocks we have mapped inboard of the fault a few kilometers to the southeast in the Alger Creek area of the Forest Falls quadrangle. These and other relations led Matti and others (1985) to propose that the Mill Creek fault is a minor strand of the San Andreas fault having no more than 8 or $9 \mathrm{~km}$ of right slip--an interpretation we favor in this report.

The age of faulting on the Mill Creek strand is not well constrained in the Yucaipa quadrangle. The fault is younger than the Miocene Warm Springs Canyon Formation, but evidence for Quaternary movement on the fault is not definitive. The fault does not break young surficial materials like those on the divide between Mill Creek and Warm Springs Canyons and on the north wall of Warm Springs Canyon; there, a large landslide mass of unknown age also conceals the trace of the fault. In Santa Ana Canyon, on the bedrock divide between Government Creek and Santa Ana River, deposits of Qoa appear to be broken by fault planes of the Mill Creek zone; however, the terrace surfaces of the deposits do not show primary fault features, and we have not confirmed whether these breaks reflect right-slip movements on the Mill Creek strand or reactivation of the strand by dip-slip tectonism. The bedrock canyon of Santa Ana River is deflected right laterally where it is crossed by the Mill Creek strand, and late Quaternary alluvial deposits nested down into this deflection could be interpreted as having been displaced westward as it evolved. However, these relations do not provide definitive information about the age of movements on the Mill Creek fault for two reasons: (1) the deflection may be do to erosional vagaries of the Santa Ana River rather than to right-lateral movements on the fault (the bedrock canyon of Government Creek is not deflected, for example), and (2) if it is the result of strike-slip displacements, the deflection of Santa Ana River canyon could have occurred before or since the deposition of late Quatemary gravels deposited in the canyon.

Wilson Creek strand.--The Wilson Creek strand traverses Yucaipa Ridge and converges toward the Mill Creek strand in Santa Ana River Canyon. The fault juxtaposes crystalline rocks of the Wilson Creek block and the overlying Mill Creek Formation against the Warm Springs Canyon Formation. The fault trace is poorly exposed in most areas, but generally dips moderately southward and has a curving, locally sinuous trace. In the adjacent Forest Falls quadrangle, beds of the Warm Springs Canyon Formation are deformed into an overturned syncline beneath the south-dipping Wilson Creek fault (J.C. Matti, unpubl. mapping, 1985-1992). A similar relation may exist in the Yucaipa quadrangle, where beds of the Warm Springs Formation dip steeply to moderately south against the Wilson Creek fault, but we have not identified facing criteria in these beds to confirm their overturned configuration.

The distribution, movement sense, and importance of the Wilson Creek fault are interpreted in different ways by different workers. Faults we assign to the Wilson Creek strand were mapped by Owens (1959) and by Smith (1959); the latter identified two fault segments (South fault and Yucaipa Ridge fault) that he thought were unrelated. Matti and others (1985) combined Smith's South and Yucaipa Ridge faults into the throughgoing Wilson Creek fault. The distribution and displacement history of the fault were examined by Demirer (1986) and by West (1987), who referred to the structure as the Yucaipa Ridge fault and restricted the name "Wilson Creek" to another fault zone in the adjacent Forest Falls quadrangle. All previous workers conclude that faults we assign to the Wilson Creek fault are minor structures having reverse dip-slip movement.

Investigators who view the Wilson Creek fault as a minor structure have been influenced by stratigraphic comparisons between the Mill Creek and Warm Springs Canyon Formations. Most workers (Dibblee, 1982; Demirer, 1986; Sadler and Demirer, 1986; West, 1987) report strong stratigraphic similarities between the two units and therefore see no need to juxtapose them along a fault having significant strike-slip movement. For reasons discussed above, we believe that stratigraphic differences between the Mill Creek and Warm Springs Formations outweigh stratigraphic similarities between them. Moreover, basement rocks of the Wilson Creek block that underlie the Mill Creek Formation are dissimilar to those in the San Bernardino Mountains east of the Wilson Creek and Mill Creek faults, and if the Mill Creek fault is a relatively minor strand of the San Andreas (as we believe), then either the Wilson Creek fault or some other (unrecognized) fault is required to bring the Wilson Creek block into the region.

We believe that the Wilson Creek fault is a significant strand of the San Andreas fault. Originally, we (Matti and others, 1985) proposed that the strand has about $110 \mathrm{~km}$ of right slip. This estimate was based on a model where the Wilson Creek and Mission Creek faults are major strands of the San Andreas that, in combination, have brought exotic rocks into the San Bernardino Mountains from their original positions as much as $150 \mathrm{~km}$ farther southeast in the Coachella Valley region. We originally believed that the Wilson Creek strand contributed considerably more of this $150-\mathrm{km}$ displacement than did the Mission Creek strand, but we acknowledged the uncertainties in this model and pointed out that an equally likely reconstruction of displaced crustal blocks could be achieved if the Mission Creek fault, rather than the Wilson Creek fault, had the larger displacement. We now adopt this role reversal between the two fault strands based on our speculation that the Wilson Creek strand is a segment of the Punchbowl fault in the San Gabriel Mountains, an old strand of the San Andreas fault for which about 40 to 45 $\mathrm{km}$ of right-slip has been documented (Ehlig, 1981; Barrows and others, 1985, 1987). We propose that the throughgoing 
Wilson Creek-Punchbowl fault was deformed into a sinuous trace following its right-lateral history, and that the Wilson Creek segment of this fault became stranded against the $S$ an Bernardino Mountains and was bypassed as movements on the younger Mission Creek strand displaced the northwest end of the Punchbowl fault (now near Palmdale) away from the southeast end of the Wilson Creek fault in the San Bernardino Mountains (Matti and Morton, 1992). If this speculation is correct, then the Wilson Creek strand has the same amount of right slip (40 to $45 \mathrm{~km}$ ) documented for the Punchbowl fault in the San Gabriel Mountains.

Mission Creek strand.--Matti and others (1985) inferred the existence of the Mission Creek fault in the Yucaipa quadrangle and elsewhere along the southwestern base of the San Bernardino Mountains in order to explain the juxtaposition of San Gabriel Mountains-type basement rocks (upper- and lower-plate rocks of the Vincent thrust) against the Wilson Creek block and rocks of San Bernardino Mountainstype. Juxtaposition of these distinctive crystalline terranes has been documented in the southeastern San Bernardino Mountains (Farley, 1979; Matti and others, 1983, 1985) where the Mission Creek fault separates rocks of San Gabriel Mountains-type from the Wilson Creek block and from rocks native to the San Bernardino Mountains. Matti and others (1985) reasoned that the Mission Creek strand continues in the subsurface along the southwestern base of the San Bernardino Mountains, where the fault continues to separate outboard rocks of San Gabriel Mountains-type from rocks of the San Bernardino Mountains and the Wilson Creek block. In the southeastern San Bernardino Mountains the Mission Creek fault is an older abandoned strand of the San Andreas (Matti and others, 1983, 1985). Likewise, in the Yucaipa quadrangle and in the San Bernardino Valley, the Mission Creek fault is an older fault that either is (1) buried under Quaternary surficial materials or (2) has been reactivated by the late Quaternary San Bernardino strand. In the latter case, the trace of the $S$ an Bemardino strand marks the trace of the older Mission Creek strand.

San Bernardino strand.--The San Bernardino strand defines the modern trace of the San Andreas fault in the Yucaipa quadrangle and elsewhere along the southwest margin of the San Bernardino Mountains. The fault breaks all but the youngest surficial materials. Northwest of Mill Creek in the Yucaipa quadrangle the fault trends $\mathrm{N} 70^{\circ} \mathrm{W}$, a trend it maintains throughout much of the San Bernardino Valley; southeast of Mill Creek, individual segments of the strand have a more northwesterly trend that averages $\mathrm{N} 55^{\circ} \mathrm{W}$.

Northwest of Santa Ana River the San Bernardino strand breaks surficial deposits we assign to units Qof and Qs; the trace is marked by scarps and trenches and by a steeply north-dipping fault plane and shear zone exposed in road cuts of the Santa Ana Truck Trail in the adjacent Redlands quadrangle. At the canyon mouth of Santa Ana River the fault's trace is buried by young sediment of units $Q f$ and $Q a i$, but the fault appears to form scarps in surficial materials we assign to units Qyf3 and Qyf 4 . The fault's trace across Santa Ana Wash is marked by a vegetation lineament that is conspicuous on vintage aerial photographs.

Between Santa Ana River and the east boundary of the Yucaipa quadrangle the San Bernardino strand becomes increasingly complex. West of the canyon mouth of Mill Creek, bedrock and surficial units are traversed by several parallel fault strands, some of which are part of the San Andreas zone; locally, these strands have north-facing scarps. None of these faults breaks youngest deposits of Mill Creek wash, but on the east side of the wash vintage aerial photographs reveal a scarp that disrupts surficial deposits we assign to unit Qyf3. A soil-profile in this unit near the Mill Creek gaging station has attributes of soil-stage S6 or S7 of McFadden (1982), and the unit probably is middle to late Holocene in age.

Southeast of Mill Creek the San Bernardino strand is complex structurally and is complicated by landslide masses that have been shed from Yucaipa Ridge. Between Mill Creek and Spoor Canyon, these landslides have conspicuous crown scarps that resemble scarps created by faults, and it is difficult to differentiate between tectonic and landslide origins for the features. However, one of the scarps is along strike from the fault scarp of the San Bernardino strand in Qyf3 of Mill Creek wash, and we tentatively identify this feature and one a few hundred meters to the north as tectonic scarps associated with that fault. The large landslide mass directly northwest of the mouth of Spoor Canyon completely obscures the San Bernardino strand, and this displaced mass of Mill Creek Formation has a lower slide plane that has crushed and sheared the bedrock units. On the west wall of Spoor Canyon it is difficult to distinguish this deformation from that caused by the fault. The antiquity of the landslide masses between Spoor Canyon and Mill Creek is unknown. Some are active, but others appear to be older slides that have stabilized under current climatic and tectonic conditions. Whatever their age, the San Bernardino strand has not displaced them laterally to any measurable degree. This reflects either (1) the youthfulness of the landslides or (2) the fact that the San Bernardino strand may step left between Spoor Canyon and Mill Creek and in the process leave most of the landslide masses effectively attached to the Yucaipa Ridge block. We tentatively favor the second interpretation.

The left-stepping geometry of the San Bernardino strand continues southeastward to the boundary of the Yucaipa quadrangle and into the adjacent Forest Falls quadrangle (Harden and Matti, 1989, fig. 2). In plan view, the fault pattem consists of short northwest-trending fault segments that pass into east-trending fault-like scarps. The latter probably are reverse faults, but we have not confirmed this speculation; in left-stepping right-lateral strike-slip fault zones, reverse dip-slip fault segments are typical (Aydin and Page, 1984; Christie-Blick and Biddle, 1985; Sylvester, 1988), and their occurrence in the Yucaipa quadrangle would be compatible with the apparent left-stepping geometry of the San Bernardino strand along this reach. Directly southeast of Spoor Canyon, stream gullies and other geomorphic features have been displaced right-laterally by the northwest-trending fault segments. This evidence for youthful right-slip on the San Bernardino strand is complemented by convincing evidence for longer-term right-slip throughout the latest Pleistocene and Holocene (Harden and Matti, 1989).

In order to determine long-term slip rates for the San Bernardino strand, Harden and Matti (1989) examined soil profiles of Qof units in the Yucaipa and Forest Falls quadrangles that contain clast populations derived from various distinctive bedrock units that crop out on Yucaipa Ridge. During Holocene and latest Pleistocene time the San Bernardino strand has displaced these alluvial-fan units right-laterally away from their source areas. Within uncertainty limits posed by the soils data and by ambiguities in the displacement paths of the alluvial-fan deposits, Harden and Matti (1989) reached two main conclusions: (1) Holcene slip rates on the San Bernardino strand probably are comparable to the $25 \mathrm{~mm} / \mathrm{yr}$ 
rates proposed for the fault in the Cajon Pass region (Weldon and Sieh, 1985; McFadden and Weldon, 1987); and (2) late Pleistocene slip rates appear to be about 6 to $13 \mathrm{~mm} / \mathrm{yr}$, considerably lower than Holocene rates. These conclusions suggest that long-term slip on the San Bernardino strand has accelerated with time. We believe that this slip-rate scenario is compatible with gradual inception of the San Bernardino strand by reactivation of the abandoned Mission Creek strand starting in late Pleistocene time, perhaps around $120,000 \mathrm{yr}$ B.P. according to Matti and others $(1985,1992)$.

\section{CRAFTON HILLS HORST-AND-GRABEN COMPLEX}

The Crafton Hills horst-and-graben complex (Matti and others, 1985, 1992) is formed by a series of documented and probable normal dip-slip faults that trends northeast from the Live Oak Canyon area to the San Andreas fault. In the Yucaipa quadrangle the complex is bounded on the northwest by the Reservoir Canyon fault and related structures (Morton, 1978) and on the southeast by the Chicken Hill fault. Faults of the complex are all late Quaternary in age, and some are youthful enough to have broken Holocene surficial units. Holocene displacements are indicated in three areas: (1) in the Live Oak Canyon area in the southwest part of the map, where a scarp and vegetation barrier are developed in Holcene deposits of unit Qf; (2) northeast of Dunlap Acres in the southwest part of the map area, where a series of documented and probable scarps disrupt deposits as young as unit Qyf3; and (3) north of Wilson Creek in the east-central part of the quadrangle, where east- and northeast-trending faults form scarps in surficial materials we assign to unit Qyf3. Field evidence for late Holocene faulting in the Yucaipa quadrangle is consistent with seismicity patterns that show abundant microseismicity beneath the Yucaipa Valley area (Green, 1983; Nicholson and others, 1986; Jones, 1988).

The structure and geometric pattern of faults of the Crafton Hills horst-and-graben complex indicates that it formed by normal dip-slip displacements. Focal-solution studies also indicate normal dip-slip mechanisms (Green, 1983; Jones, 1988), although a left-lateral component may be present (Nicholson and others, 1986). The existence of a normal dip-slip fault complex in a region characterized by right-lateral strike-slip faults of the San Andreas family and by contractional reverse and thrust faults of the Transverse Ranges Province seems anomalous. Matti and others (1985) resolved this paradox by proposing that normal faults of the Yucaipa-Crafton Hills area reflect an extensional domain that occupies the greater San Bernardino Valley area as the consequence of a regional right step that occurs between the $S$ an Jacinto fault and the San Bernardino strand of the San Andreas fault. This extensional domain has led to normal dip-slip faults that have downdropped the Yucaipa Valley graben and uplifted the Crafton Hills horst.

The age of the horst-and-graben complex in the Yucaipa quadrangle provides insight into the timing of the right step between the San Jacinto and San Andreas faults. The Crafton Hills horst was elevated after the deposition of surficial unit Qvoa 1 in the Live Oak Canyon and Sand Canyon areas. This unit may be as young as $750 \mathrm{Ka}$ to $500 \mathrm{Ka}$. If so, then extensional effects created by the region-wide right step began to affect the Yucaipa area by that time. Extensional faulting continued throughout the late Pleistocene and influenced depositional patterns within units of Qoa and Qof.

\section{OTHER FAULTS}

Greenspot fault.--We apply the name Greenspot fault to a scarp-like structure of probable tectonic origin east of Santa Ana Wash that disrupts deposits we assign to units Qvof $_{1}$ and Qof 2 . This structure is flanked $1 / 4$ mile to the east by a sub-parallel scarp-like feature that probably also is tectonic in origin. The Greenspot fault appears to be a normal dip-slip structure that drops Quaternary units down to the west. The fault probably is the northward continuation of the contemporaneous Reservoir Canyon fault, in which case the Greenspot fault would be a bounding structure of the Crafton Hills horst.

Mill Creek thrust.--We apply the name Mill Creek thrust to a low-angle reverse fault that breaks older and younger surficial deposits west of the canyon mouth of Mill Creek. The thrust forms a scarp in deposits we assign to unit Qyf $_{1}$, and traverses units Qvof 1 and Qof 1 . We do not understand the tectonic role of the Mill Creek thrust. However, it occurs northwest of Mill Creek where the San Bernardino strand of the $S$ an Andreas fault changes regional strike from $\mathbf{N}$ $55^{\circ} \mathrm{W}$ to $\mathrm{N} 70^{\circ} \mathrm{W}$, and this deflection may trigger contraction outboard (west) of the San Bernardino strand due to angular convergence between the two right-lateral segments. A clearer picture of the origin and role of the Mill Creek thrust must await more careful mapping in its poorly exposed outcrop belt.

Banning fault.--The Banning fault is a major right-lateral strike-slip fault that crops out in the San Gorgonio Pass region to the southeast and in the adjacent El Casco quadrangle (Matti and others, 1985, 1992). There, the fault juxtaposes rocks of San Gabriel Mountains-type on the north against the San Timoteo Formation to the south. Projected northwestward from its last outcrop in the El Casco quadrangle, the Banning fault would cross the Yucaipa quadrangle approximately along the dotted trace we infer for the fault in the southwest part of the map. We observed no evidence that the Banning fault breaks Quaternary deposits of the San Timoteo Formation along this trace.

\section{APPENDIX 1 DESCRIPTION OF MAP UNITS}

Qa, Qf, Qc, Qw

Sediment actively transported and deposited in channels and washes, on surfaces of alluvial fans and alluvial plains, and on hill slopes (Holocene). Soil-profile development is non-existent to minimal. In some areas, adjacent units separated into alluvial-fan and alluvial-plain deposits have similar lithologic attributes, but are shown as separate units in order to emphasize contrasts in their depositional origins and geomorphic settings. Includes:

and rivers;

Qw Deposits in channelized washes of streams

Qa Deposits of alluvial plains and valley

floors;

Qai Intermittently active deposits of alluvial plains and valley floors; 


\begin{tabular}{|c|c|}
\hline Qf & Deposits of alluvial fans; \\
\hline Qfi & Intermittently active deposits of alluvial \\
\hline $\begin{array}{r}\text { Qc } \\
\text { slope-wash. }\end{array}$ & Colluvial deposits of scree, talus, and \\
\hline Qya & YOUNG DEPOSITS OF ALLUVIAL \\
\hline
\end{tabular}

PLAINS (Holocene and late Pleistocene). Slightly to moderately consolidated silt, sand, and gravel with slightly to moderately developed pedogenic soil profiles (A/C to $\mathrm{A} / \mathrm{AC} / \mathrm{B}_{\text {cambic }} / \mathrm{C}_{\text {ox }}$ profiles). The units are distinguished from each other on the basis of soil-profile development, relative position in the local terrace-riser succession, and degree of erosional dissection. Includes:

Qyas Occurs only in south part of map area, where unit forms upper part of the late Quaternary deposit that fills the valleys of Oak Glen and Yucaipa Creeks. Deposit consists mainly of thin- to thick-bedded very fine to medium sand that varies from white and light gray (10YR $8 / 1$ and $7 / 1$ ) to very pale brown (10YR $8 / 3$ and $8 / 4$ to $7 / 3$ ). The sand is interlayered with subordinate pebbly fine sand and dark-colored organic-rich layers. Deposit commonly capped by weak A/C soil (San Emigdio fine sandy loam of Woodruff and Brock, 1980, map sheet 10). Unit incised by Yucaipa and Oak Glen Creeks;

Qya 4 Occurs in east-central part of map area in the valleys of Oak Glen and Wilson Creeks. In some places, unit forms a thin veneer that rests on a strath terrace incised into unit Qya3; in other places, unit forms a low terrace riser standing a meter or less above the active wash. Unit consists of pale brown and very pale brown (10YR $6 / 3$ to $8 / 3$ ) fine to coarse sand and pebbly sand that coarsens upstream to poorly sorted fine to coarse sand and sandy pebble-small cobble gravel. Unit capped by weak $\mathrm{A} / \mathrm{AC} / \mathrm{C}_{\text {ox }}$ soils (Hanford coarse sandy loam and Tujunga loamy sand of Woodruff and Brock, 1980, map sheet 10 );

Qya3 Occurs in east-central part of map area in the valleys of Oak Glen and Wilson Creeks, where unit forms a terrace riser standing 1 to $2 \mathrm{~m}$ above the active wash. Unit probably is no more than 2 to $5 \mathrm{~m}$ thick, and consists of pale brown and very pale brown (10YR $6 / 3$ to $7 / 3$ and $7 / 4$ to $8 / 4$ ) fine to coarse sand and pebbly sand that coarsens upstream to poorly sorted fine to coarse sand and sandy pebble/smallcobble gravel. Unit capped by weak to moderate $\mathrm{A} / \mathrm{AC} / \mathrm{C}_{\mathrm{ox}}$ soils (Tujunga loamy sand and gravelly loamy sand of Woodruff and Brock, 1980; locally includes Soboba gravelly loamy sand). The unit represents an aggradational event in the Yucaipa Valley region, and formed as fluvial sediment backfilled valleys and buttressed unconformably against highstanding older alluvial deposits;

Qya2 Unit mapped in adjacent quadrangles but not recognized in map area;

Qya 1 Occurs in central part of map area in the valley of Oak Glen Creek, where unit forms a terrace riser standing several meters above the active wash. Unit probably is no more than $5 \mathrm{~m}$ thick and consists of pale brown and very pale brown (10YR $6 / 3$ to $8 / 3$ ) fine to very coarse sand and pebbly sand that coarsens upstream to poorly sorted sand and sandy pebble/small-cobble gravel. Unit is capped by moderately developed $\mathrm{A} / \mathrm{AC} / \mathrm{B}_{\text {cambic }} / \mathrm{C}_{\text {ox }}$ soils (grouped variously by Woodruff and Brock, 1980, into Greenfield and Tujunga loamy sand and sandy loam and Oak Glen gravelly sandy loam). In Yucaipa Valley region, the unit formed as fluvial sediment backfilled valleys and buttressed unconformably against high-standing older alluvial deposits. Unit is part of a major region-wide fill that was deposited throughout the San Bernardino Valley region during the transition between late Pleistocene and Holocene (McFadden and Weldon, 1987; Morton and Matti, 1987).

\section{Qy YOUNG DEPOSITS OF ALLUVIAL} FANS (Holocene and latest Pleistocene). Slightly to moderately consolidated sand and gravel with slight to moderately developed pedogenic soils ( $A / C$ to $A / A C / B_{\text {cambic }} / C_{o x}$ profiles). The units are distinguished from each other on the basis of soil-profile development, relative position in the local terrace-riser succession, and degree of erosional dissection. Includes:

Qyf4 Forms extensive slightly dissected deposits downstream from the canyon mouths of Mill Creek and Santa Ana River. Consists of sandy cobble-boulder gravel and poorly sorted gravelly sand that is white (10YR $8 / 1$ to $8 / 2)$ to light gray (10YR 7/1). Unit capped by thin A/C soil (Soboba stony loamy sand of Woodruff and Brock, 1980, map sheet 10);

Qyf3 Forms remnant terrace risers downstream from canyon mouths of Mill Creek and Santa Ana River; consists of sandy pebble-cobble-boulder gravel and poorly sorted gravelly sand that is white (10YR $8 / 2$ ) to very pale brown (10YR $8 / 3$ to $8 / 4$ ). Also forms fine-grained alluvial-fan cones that flank the Crafton Hills, Yucaipa Ridge, and the San Bernardino Mountains, and that locally accumulated downslope from fault scarps of the Yucaipa Valley graben. Unit capped by medium to thick $\mathrm{A} / \mathrm{C}$ and $\mathrm{A} / \mathrm{AC} / \mathrm{C}_{\text {ox }}$ soils (Hanford coase sandy loam and Oak Glen gravelly sandy loam of Woodruff and Brock, 1980, map sheet 10). Deposit appears to form a significant mid-Holocene fill;

Qyf $f_{2}$ Unit occurs as local deposits of pebbly and cobbly sediment in the east-central part of the map area;

Qy $\mathbf{f}_{1}$ In east-central part of map area unit consists of sand-and-gravel deposits that form small alluvial fans flanking Yucaipa Ridge (Soboba stony loamy sand of Woodruff and Brock, 1980, map sheet 10). These deposits have a $B_{\text {cambic }}$ horizon and well developed $C_{o x}$ horizon as described by Harden and Matti (1989). East of the mouth of Mill Creek Canyon unit consists of pinkish gray pebbly sand deposits that form a veneer a few meters thick on older deposits. The unit appears to form a major fill that was deposited throughout the San Bernardino Valley region during transition between late Pleistocene and Holocene (McFadden and Weldon, 1987; Morton and Matti, 1987).

Qoa OLD DEPOSITS OF ALLUVIAL FLOOD PLAINS (late Pleistocene). Moderately to well consolidated silt, sand, and gravel with moderate to well 
developed pedogenic soils ( $A / A B / B / C_{o x}$ profiles with $B_{t}$ horizons). The units are distinguished from each other on the basis of soil-profile development and relative position in the local terrace-riser succession. Consists of two main deposits (Qoa1 and Qoa2) that filled valley areas as the result of deposition by Oak Glen and Yucaipa Creeks and their tributaries. A third older alluvial deposit (Qoa3) is a thin veneer that overlies a strath terrace cut in to Qoa2. Qoa rests unconformably on underlying San Timoteo Formation. Includes:

Qoa3 Alluvial-plain deposit that forms a thin veneer of sand and pebbly sand overlying a strath terrace incised into unit Qoa2. Capped by soils having thin to moderate $B_{t}$ horizons (Greenfield soils of Woodruff and Brock, 1980). Unit occurs only in south-central part of the map area;

Qoa2 Moderately dissected interstratified sand and gravel capped by soils having $B_{t}$ horizons as much as $\mathbf{5 0}$ $\mathrm{cm}$ thick (Ramona soils of Woodruff and Brock, 1980). Unit occurs in the south-central and east-central parts of the map area. In the valley of Oak Glen Creek, unit Qoa2 forms a widespread fill more than $10 \mathrm{~m}$ thick that rests unconformably on unit Qoa1; on the bench beneath the City of Yucaipa, unit $\mathrm{Qoa}_{2}$ is more restricted in distribution and forms a thin veneer deposited on a strath incised into Qoa1;

Qoa 1 Moderately dissected interstratified sand and gravel capped by soils having $B_{\mathfrak{t}}$ horizons as much as 50 to $150 \mathrm{~cm}$ thick (Ramona soils of Woodruff and Brock, 1980). Unit occurs in east part of map area. In the valley of Oak Glen Creek, Qoa 1 consists of poorly sorted sand and pebblecobble-boulder gravel that locally is preserved beneath overlying unit Qoa2. In Yucaipa Valley, Qoa1 forms a widespread body deposited by streamflows of Yucaipa and Oak Glen Creeks that converged southwest and flowed down ancestral Live Oak Canyon.

Contact relations between Qoa 1 and underlying San Timoteo Formation are ambiguous but probably unconformable. Along the axes of Yucaipa and Oak Glen Creeks, Qoa 1 is relatively thick (a few tens of meters) and appears to occupy major channels incised erosionally into the San Timoteo Formation. On high-standing terraces between Oak Glen and Yucaipa Creeks and south of Yucaipa Creek, Qoa 1 is relatively thin and appears to feather out to the southwest on top of the San Timoteo Formation. This relation can be observed best south of Yucaipa Creek, where Qoa 1 feathers out southwestward into isolated bodies and patches of reddish sediment that may consist partly or entirely of pedogenic soil developed on top of the San Timoteo Formation. These relations can be explained only if deposits of Qoa 1 rest unconformably on a San Timoteo surface that had erosional relief. This interpretation is difficult to defend, however, in areas where Qoa 1 passes transitionally downsection into deposits of the San Timoteo Formation that are very similar lithologically.

Qof OLD DEPOSITS OF ALLUVIAL FANS (late Pleistocene). Moderately to well consolidated silt, sand, and gravel with moderate to well developed pedogenic soils $\left(\mathrm{A} / \mathrm{AB} / \mathrm{B} / \mathrm{C}_{\text {ox }}\right.$ profiles with $\mathrm{Bt}$ horizons). The units are distinguished from each other on the basis of soil- profile development and relative position in the local terraceriser succession. Includes:

Qof3 Moderately dissected inter-stratified sand and gravel capped by soils having $B_{t}$ horizons a few tens of centimeters thick (Greenfield soils of Woodruff and Brock, 1980). Unit occurs in alluvial fans that flank Yucaipa Ridge and the San Bernardino Mountains west of the mouth of Mill Creek Canyon;

Qof 2 Moderately dissected interstratified sand and gravel capped by soils having $B_{t}$ horizons as much as 50 $\mathrm{cm}$ thick (Ramona soils of Woodruff and Brock, 1980). Unit occurs in alluvial fans that flank the Crafton Hills, Yucaipa Ridge, and the San Bernardino Mountains;

Qof 1 Moderately dissected inter-stratified sand and gravel capped by soils having $B_{t}$ horizons as much as 50 to $150 \mathrm{~cm}$ thick (Ramona soils of Woodruff and Brock, 1980.

Qvoa VERY OLD DEPOSITS OF ALLUVIAL PLAINS (late Pleistocene). Well consolidated sediment with well developed pedogenic soils. Includes:

Qvoa1 Well dissected sand and gravel capped by $\mathrm{A} / \mathrm{AB} / \mathrm{B} / \mathrm{C}_{\text {ox }}$ soils having $\mathrm{B}_{\mathrm{t}}$ horizons as much as 1 to $2 \mathrm{~m}$ thick (Ramona soils of Woodruff and Brock, 1980). Occurs mainly in southwest part of map area where the unit rests conformably on the San Timoteo Formation. In the vicinity of Sand Canyon, Qvoa 1 consists of brownish yellow (10YR 6/6 to $6 / 8$ ) to dark yellowish brown (10YR 4/4) sand and gravel layers interstratified with $\mathrm{B}_{\mathrm{t}}$-bearing paleosols having 7.5YR to 5YR hues. In the hills north of Live Oak Canyon, Qvoa 1 is uniformly more reddish in color, is more dissected, and the pedogenic surface soil is thicker and better developed. There, materials locally mapped as Qvoa 1 are similar lithologically to underlying deposits of the San Timoteo Formation, and the reddish coloration partly may be a pedogenic regolith developed on the San Timoteo Formation.

\section{Qvof VERY OLD DEPOSITS OF} ALLUVIAL FANS (late Pleistocene). Well consolidated sediment with well developed pedogenic soils. Includes:

Qvof 1 Well dissected sand and gravel capped by $\mathrm{AB} / \mathrm{B} / \mathrm{C}_{\text {ox }}$ soils having $\mathrm{B}_{\mathrm{t}}$ horizons as much as 1 to $2 \mathrm{~m}$ thick (Ramona soils of Woodruff and Brock, 1980). Locally forms relict alluvial-fan deposits around margins of the Crafton Hills, but mainly occurs southwest of the San Bernardino strand of the San Andreas fault between Mill Creek and the Santa Ana River. There, Qvof 1 consists of interlayered sand, gravelly sand, and sandy cobble-boulder gravel; the sand intervals and matrix in the gravel layers is very pale brown to light yellowish brown (10YR $8 / 4$ to $6 / 4$ ). The clasts are rounded to subangular, and consist of sandstone derived from the Mill Creek Formation as well as various granitoid and gneissose rock types derived from crystalline bedrock sources in the San Bernardino Mountains east of the Mill Creek strand of the San Andreas fault. 


\section{ROCKS EAST OF THE MILL CREEK STRAND, SAN ANDREAS FAULT}

\section{Tm PORPHYRITIC MONZO-GRANITE} (Triassic). Medium to coarsely crystalline porphyritic hornblende-biotite monzogranite to quartz monzonite characterized by euhedral to subhedral phenocrysts of potassium feldspar as much as $5 \mathrm{~cm}$ in dimension. Emplacement age of $215 \mathrm{Ma}$ determined by the U/Pb method (Frizzell and others, 1986). Rock is intruded by dikes and small bodies of fine to coarsely crystalline biotite granodiorite to monzogranite and dikes of mafic hornblende-rich rock; biotite granodiorite locally is dominant rock type.

\section{CENOZOIC AND MESOZOIC ROCKS BETWEEN THE MILL CREEK AND WILSON CREEK STRANDS, SAN ANDREAS FAULT}

Tw FORMATION OF WARM SPRINGS CANYON (Miocene?). Nonmarine sandstone and conglomerate. Unit occupies the same structural position as unnamed sedimentary rocks mapped by Morton and Miller (1975, figs. $1 \mathrm{c}-1 \mathrm{~g}$ ) along the southwest margin of the San Bernardino Mountains; mapped as Mill Creek Formation by Gibson (1964, 1971) and by West (1987), as Potato Sandstone by Dibblee (1982), and as Potato Formation by Hillenbrand (1990). Base faulted against orthogneiss of Alger Creek, but equivalent deposits in adjacent Forest Falls quadrangle rest depositionally on crystalline rocks of the San Bernardino Mountains block (J.C. Matti, unpubl. mapping, 1988-1991). Upper contact is erosional.

Consists of heterogeneous sedimentary rocks dominated by well sorted to poorly sorted sandstone, conglomerate, and conglomeratic sandstone interlayered with mudrock in some stratigraphic intervals. Conglomerate: Medium- to very thick-bedded pebble-cobble conglomerate and conglomeratic sandstone. Conglomerate intervals are dominantly pinkish gray, but also are yellowish-gray to pale brownish depending on composition of matrix and clasts. Typical pinkish hues include pinkish gray, reddish gray, and reddish brown $(5 Y R 7 / 2,6 / 2,5 / 2$, and $5 / 3)$, pale red (10R $6 / 2$ ), and grayish red purple (5RP 4/2). Yellowish gray and light-brown hues include white to pale yellow (2.5Y $8 / 2$ to $7 / 4$ ) and white to very pale brown (10YR 8/1 through 8/4). Clasts range from pebbles to large cobbles, although typically are in the pebble and small-cobble range. They are subangular to subrounded, and are dominated by leucocratic to mesocratic gneissose rocks and leucocratic granitoid rocks; greenish hornblende diorite-gabbro clasts are minor but distinctive components. Sandstone: Several kinds of sandstone occur. Greenish fine-grained sandstone:--Thin- to medium-bedded, moderately to well sorted, fine to coarse lithic and feldspathic sandstone that is parallel bedded and is texturally massive to flat laminated and cross laminated. Pillow-and-ball structure is developed locally. These rocks typically are greenish and grayish colored; representative hues include light olive gray to pale olive ( 5 Y $6 / 2$ to $5 / 2$ ), olive gray $(5 Y 4 / 2$ to $5 / 2)$, and light gray $(5 Y 7 / 2)$. These sandstones commonly are associated with greenish colored mudrock intervals, and the sandstone-mudrock intervals resemble generally similar intervals in the Mill Creek Formation. Buff to grayish arkosic sandstone:--Thin- to thick-bedded, moderately to poorly sorted, fine to very coarse lithic and feldspathic sandstone and pebbly sandstone that is texturally massive to flat laminated and cross laminated (including shallow trough laminations). These rocks typically are grayish to buff colored; representative hues include white (10YR $8 / 1$ and $8 / 2$ to $2.5 \mathrm{Y} 8 / 2)$, light gray (10YR $7 / 1$ to $7 / 2$ ), and very pale brown (10YR $8 / 3$ to $8 / 4$ ). Pinkish gray to reddish sandstone:--Compositionally and texturally immature rocks that are medium- to very thick-bedded, moderately to poorly sorted, medium to very coarse lithic and feldspathic sandstone and pebble-granule-bearing sandstone that is texturally massive to laminated and cross laminated, including large-scale trough laminations and tabular cross laminations. Quartz, feldspars, and lithic framework grains are angular to subrounded, and biotite and muscovite are common accessory minerals. Lenticular bedding geometry is common locally. These rocks typically are pinkish to reddish colored; representative hues include pinkish gray, reddish gray, and reddish brown $(5 Y R 7 / 2,6 / 2,5 / 2$, and $5 / 3$ ), pale red (10R 6/2), and grayish red purple (5RP 4/2). Mudrock: Recessive, laminated to medium bedded grayish green to brownish siltstone, mudstone, and claystone. The mudrock generally is texturally massive, but faint to well developed flat to irregular lamination is common.

MZga ORTHOGNEISS OF ALGER CREEK (Mesozoic?). Light-gray fine to medium crystalline biotitehornblende granodiorite having well developed lenticular laminated fabric created by streaks of quartz, pink feldspar, and mafic aggregates. Locally encloses thin lenses of dark foliated amphibolite. Unit commonly is sheared and fractured, and weathers to dark brown color. Named for Alger Creek in the adjacent Forest Falls 7.5' quadrangle where the unit crops out directly northeast of the Mill Creek strand of the San Andreas fault (B.F. Cox and J.C. Matti, unpublish. mapping, 19781980).

\section{CENOZOIC AND MESOZOIC ROCKS BETWEEN THE SAN BERNARDINO AND WILSON CREEK STRANDS OF THE SAN ANDREAS FAULT}

These rocks comprise the Wilson Creek block of Matti and others $(1985,1992)$.

Qs SURFICIAL DEPOSITS (Quaternary). Moderately to well consolidated, light yellowish brown to yellowish brown (10YR 6/4 to 5/4), medium to very thick bedded, texturally massive to laminated, poorly sorted, fine to very coarse sandstone interstratified with subordinate pebbly sandstone and granule-pebble conglomerate. Clasts subangular to subrounded, consist of granitoids and gneissose granitic rock derived from the underlying Wilson Creek block. Rests nonconformably on crystalline rocks of Wilson Creek block and represents colluvial, fluvial, and alluvial-fan deposits.

Tm MILL CREEK FORMATION OF GIBSON (1971) (Miocene). Nonmarine claystone, mudstone, sandstone, and conglomerate; probably late Miocene (Woodburne, 1975). Nonconformably overlies crystalline rocks of Wilson Creek block; upper contact is erosional. Gibson $(1964,1971)$ applied the name Mill Creek Formation 
to outcrops Vaughan (1922) originally grouped within his Potato Sandstone. Vaughan's original characterization of the Potato Sandstone was only generalized, and since that time sedimentary rocks within the Potato outcrop belt have been mapped and classified differently by various workers (Smith, 1959; Owens, 1959; Gibson, 1964, 1971; Dibblee, 1982; Matti and others, 1985, 1992; Demirer, 1985; West, 1987; Hillenbrand, 1990). We restrict the name Mill Creek Formation to beds between the San Bernardino and Wilson Creek strands of the San Andreas fault.

Lithologies include: Conglomerate: Ledgeforming, medium- to very thick-bedded, sandy pebble and small-cobble conglomerate and conglomeratic sandstone. Conglomerate intervals are yellowish to grayish to palebrown depending on matrix and clast composition; representative hues include pale yellow (5Y $8 / 3$ to $7 / 3$ ), light gray, white, and pale yellow $(2.5 \mathrm{Y} 7 / 2,8 / 2$, and $8 / 4)$, and white, light gray, and very pale brown (10YR $8 / 1$ to $8 / 3$ and $7 / 1$ to $7 / 3$ ). Beds are lenticular on a scale of tens to hundreds of meters. Depositional fabrics mainly are grain supported and fluvial in origin; matrix-supported debris-flow fabrics are rare. Clast sizes range from pebbles to medium cobbles, and are rounded to subangular. Clast populations are dominated by leucocratic to mesocratic granitoid and gneissose types but locally include Pelona Schist and volcanic clasts. Sandstone: Ledgforming, thin- to thick-bedded, poorly sorted to well sorted very fine to coarse lithic and feldspathic sandstone. Beds generally are lenticular over distances of a few tens of meters to several hundred meters; more persistant strata are parallel bedded. Sandstone intervals are yellowish to grayish to pale brown depending on grain size, biotite content, and framework-grain composition; representative hues include pale yellow to light yellowish brown (2.5Y $7 / 4$ to $6 / 4$ ), light gray (10YR $7 / 1$ and $7 / 2$ to $2.5 Y 7 / 2$ ), olive gray to gray ( $5 \mathrm{Y} 5 / 1$ to $5 / 2)$, light gray to light brownish gray $(2.5 \mathrm{Y}$ $7 / 2,6 / 2$ ), and very pale brown to light yellowish brown (10YR $8 / 3$ and $7 / 3$ to $6 / 4$ ). Textures vary from massive to flat laminated to cross laminated to graded; some sand beds are convolute-laminated and locally have pillow-and-ball structure. Most sandstones are fluvial in origin, but some were deposited from turbidity currents and sediment-gravity flows in lacustrine settings. Mudrock: Recessive, very thin- to medium-bedded claystone, mudstone, siltstone, and very fine sandstone. Mudrock intervals are distinctly greenish to brownish colored. Representative hues for fresh rock include gray and greenish gray (5Y $5 / 1$ to $5 \mathrm{GY} 5 / 1)$, olive gray to gray ( $5 \mathrm{Y} 5 / 2$ and $4 / 2$ to $4 / 1$ ), pale olive $(5 Y 6 / 3)$, grayish brown to brown and dark grayish brown (10YR $5 / 2$ to $5 / 3$ and $4 / 3$ ), and pinkish gray (7.5YR 6/2); weathering colors are more reddish and brownish, including pale red (5R 6/2 to $10 \mathrm{R} 6 / 2$ ), reddish gray (5YR 5/2), and reddish brown to dark reddish brown (5YR $4 / 3$ to $3 / 3$ ) to dark yellowish brown (10YR 4/4). The mudrock generally is texturally massive, but faint to well developed flat to irregular lamination is common. Mudcracks occur locally, and flat-pebble conglomerate or conglomeratic sandstone associated with the mudrock intervals may represent rip-up breccias. Dark organic fragments are abundant in some mudrocks together with deciduous and coniferous plant fossils studied by Axelrod (in Smith, 1959, p. 31-33 and in Gibson, 1964 , p. 8-9).

We recognize informal subunits of the Mill Creek Formation based on the overall lithologic character of the stratigraphic interval:
T ms Stratigraphic interval where sandstone predominates over mudrock;

Tmm Stratigraphic interval where mudrock predominates over sandstone;

Tma Stratigraphic interval dominated by palebrown to yellowish weathering sandstone that is so feldspathic we describe it as arkosic. Typical hues include very pale brown to pale brown (10YR $7 / 3$ to $7 / 4,6 / 3$ ), light gray (5Y 6/1 and 10YR 7/2), yellow (10YR $7 / 6$ to 7/8) and light yellowish brown (10YR 6/4). Pebbly and cobbly sandstone and conglomerate lenses locally abundant; clasts are rounded to subangular, consist mainly of leococratic granitoid and gneissose rocks, some muscovite-bearing. Framework grains and conglomerate matrix feldspar-rich and locally muscovite-bearing. Contact with Tmm is gradational;

T $\mathbf{m v}$ Unit of ledgeforming, thick- to very thickbedded, buff-weathering moderately to well sorted fine to coarse sandstone and pebble-cobble-bearing sandstone containing aplitic, granitoid, and gneissose clasts but characterized by rounded to subrounded pebbles and small cobbles of volcanic rock (latite, quartz latite, basaltic andesite, and andesite). Representative sandstone hues include very pale brown to light gray (10YR $7 / 3$ to $7 / 2$ ) and pale olive to light gray (5Y $6 / 4$ to $7 / 2)$;

Tmc Unit of ledgeforming, thick- to very thickbedded, brownish-gray to greenish-gray weathering, moderately to poorly sorted coarse sandstone, pebbly sandstone, and pebble-cobble conglomerate characterized by clasts of bluish gray coarsely crystalline Pelona Schist and dark green gneissose diorite. Representative sandstone hues include dark grayish brown to grayish brown (10YR $4 / 2$ to $5 / 2$ and $2.5 \mathrm{Y}$ $4 / 2$ to $5 / 2)$ ), light olive gray to olive gray $(5 Y 6 / 2$ to $5 / 2)$, and gray to greenish gray (5Y $6 / 1$ to $5 / 1$ and 5 GY $6 / 1$ to $5 / 1$ ). Sandstone and conglomerate rich in Pelona Schist debris tend to be lighter colored and greenish gray; rock rich in dioritic and granitoid debris tends to be darker colored and brownish gray. Clasts are subrounded to angular, pebbles to large cobbles. In addition to Pelona Schist and gneissose diorite, clasts include intermediate granitoids, milky vein quartz, leucocratic aplitic rock, and rare volcanic rocks. Paleocurrents for Pelona Schist-bearing conglomerate indicate streamflows from south to north and southwest to northeast (contrast with Gibson, $1964,1971)$. Schist clasts are similar to bedrock of unit ps, that depositionally(?) underlies the Mill Creek Formation in east part of quadrangle.

ps 2 PELONA SCHIST (Mesozoic protolith). Dark blue-green to light-gray, medium to coarsely crystalline porphyroblastic chlorite-albite-actinolite greenstone schist and light gray to yellowish gray quartzofeldspathic schist. Relations with other rock units unclear. Unit ps2 is a distinctly different facies of Pelona Schist than occurs in the Crafton Hills southwest of the San Bernardino and Mission Creek strands of San Andreas fault. Lithologically similar to Pelona Schist in Blue Ridge window of Pelona Schist in southeastern San Gabriel Mountains (Smith, 1959). Relation with Miocene Mill Creek Formation (Mm) undocumented; probably overlain nonconformably by $\mathbf{M m}$, but may be landslide sheet interlayered with $\mathrm{Mm}$ or (less likely) fault slice juxtaposed with $\mathbf{M m}$. 


\section{Mzgg GNEISSOSE GRANITOID ROCK} (Mesozoic). Crystalline rocks characterized by compositional and textural heterogeneity. Dominant feature is gneissose fabric created by faint to conspicuous compositional layering of mafic-rich and mafic-poor layers. Compositional layering is developed at all scales, ranging from millimeter and centimeter lamination to layering on outcrop and hillside scales. Mafic layers are biotite-rich and typically are foliated; felsic layers are quartzofeldspathic and texturally massive to foliated, depending on whether fabric is equigranular or lenticular. In thin section, quartz has slight to profound undulatory extinction and some plagioclase and K-feldspar are ragged, polydomained, and strained. Mafic-rich layers generally are granodioritic to tonalitic; mafic-poor quartzofeldspathic layers mainly are biotite-bearing granodiorite, but include monzogranite, tonalite, and less common quartz-poor rock that is quartz monzodioritic. Contacts between biotite-rich and quartzofeldspathic layers may be either sharp or transitional, with both kinds of boundary occurring in the same outcrop. Transition zones commonly are marked by wispy discontinuous layering that resembles schlieren. Intermixed with the compositionally-layered rocks are inclusion-rich zones containing xenoliths and (or) inclusions and (or) dismembered and attenuated mafic dikes of diorite-gabbro and mafic granitoid rock; some of these are mappable (unit Mzi), but most are only a few meters wide and cannot be mapped laterally. The crystalline complex locally is traversed by low-angle shear zones, and the rocks are highly fractured.

The origin and age of $\mathrm{Mzgg}$ are problematical. Previous workers interpret the crystalline complex as a Precambrian metamorphic terrane intruded by Mesozoic plutons like the Diorite of Cram Peak (see Rogers, 1967, who compiled the unpublished work of T.W. Dibblee, Jr.; Dibblee, 1964; Dibblee, 1968, 1975, 1982). Without question, gneissose fabrics of the crystalline complex reflect deformation that has physically rearranged mineral phases that originally were texturally and compositionally more homogeneous; deformation also is indicated by partly and wholly recrystallized textures. However, the genetic implication of these features to us is ambiguous. The deformational fabrics pass transitionally into equigranular fabrics that show little evidence of deformation. Moreover, cross-cutting relations between deformed and undeformed rocks are not common; instead, the two fabric types commonly are interlayered. We tentatively interpret the crystalline complex largely as a plutonic terrane that was deformed during or subsequent to intrusion; the foliated and gneissose fabrics probably represent reorganized plutonic fabrics that originally were equigranular. We presently cannot resolve whether texturally massive fabrics are high-strain metamorphic rocks with granoblastic texture or low-strain rocks with original plutonic fabrics preserved. The complex probably is entirely Mesozoic in age, although Precambrian gneiss may occur locally within the complex.

\section{Mzg GRANITOID ROCK (Mesozoic). Light-} gray to pinkish gray texturally massive to slightly foliated, medium to coarsely crystalline biotite-bearing leucocratic granitoid rock that is monzogranitic to granodioritic in composition. Rock locally has $\mathrm{K}$-feldspar phenocrysts as much as $1 \mathrm{~cm}$ in dimension.
Mzgr MESOCRATIC GRANITOID ROCK (Mesozoic). Fine to coarsely crystalline granodiorite, tonalite, and quartz diorite that is highly weathered.

MZi INCLUSION-RICH GRANITOID ROCK (Mesozoic). Narrow elongate zones of mafic inclusions enclosed by gneissose granitoid rock (Mzgg). Most inclusions are dioritic to quartz dioritic, but some are gabbroic. Inclusions typically are flattened and ovoid.

MEc DIORITE OF CRAM PEAK (Mesozoic). Medium to coarsely crystalline, texturally massive to slightly foliated, equigranular hornblende diorite and quartz diorite. Relations with $\mathrm{Mz} g$ g not determined: some outcrops suggest Mzc intrudes Mzgg; other outcrops suggest $\mathrm{M} z \mathrm{gg}$ formed in part by deformation of $\mathrm{Mzc}$ and related rocks.

\section{CENOZOIC AND MESOZOIC ROCKS WEST OF THE SAN BERNARDINO AND MISSION CREEK STRANDS OF THE SAN ANDREAS FAULT}

\section{QTST FORMATION OF SAN TIMOTEO}

CANYON (Pleistocene and Pliocene). Nonmarine sandstone and conglomerate. In the map area these rocks form the upper part of a thick sedimentary sequence referred to originally by Frick (1921) as Tertiary Deposits of the San Timoteo Badlands, specifically his "Upper San Timoteo Deposition" (Frick, 1921, p. 317-318) . In the Yucaipa quadrangle the unit consists mainly of medium- to thick-bedded, moderately to well sorted very fine to coarse sandstone interlayered with subordinate pebbly sandstone and pebble to small-cobble gravel. Depositional textures range from texturally massive to flat laminated and cross laminated. Stratification is defined by variations in grain size, color, and depositional fabric. Sandstone intervals are distinctly yellowish colored throughout much of the unit, with representative hues including light yellowish brown to olive yellow (2.5Y $6 / 4$ to $6 / 6)$ and light olive brown (2.5Y 5/6); toward the top of the unit the beds are more brownish, including brownish yellow to yellowish brown (10YR $6 / 6$ to $5 / 6$ ) and strong brown (7.5YR $6 / 6$ to $5 / 6)$. The sandy matrix of gravel beds is lighter colored than the typical sand beds, and ranges from light gray to pale yellow and light yellowish brown $(2.5 \mathrm{Y} 7 / 2$ to $6 / 4)$. Clasts in the gravel layers are subrounded to subangular, and represent most of the local basement rocks in the quadrangle, including Pelona Schist, granitoids from the upper plate of the Vincent thrust, and granitoid and gneissic rocks of San Bernardino Mountains-type derived from Yucaipa Ridge. The sand-andgravel sequence intermittently encloses reddish colored clayand silt-rich layers as much as $40 \mathrm{~cm}$ thick that pass gradationally downward into yellowish gray oxidized sediment; these intervals appear to be paleosols with $\mathrm{B}_{\mathrm{t}}$ horizons (10YR $5 / 6$ to $4 / 6$ to 7.5 YR $5 / 6$ to $6 / 6$ ) and $C_{o x}$ horizons. The unit is cut by fractures and small faults that locally are filled or lined with caliche; pedogenic(?) carbonate is abundant subjacent to contacts between the $\mathrm{S}$ an Timoteo Formation and overlying older alluvial deposits.

Lower contact of the unit is not exposed in the map area. Upper contact with overlying rock units has a different character from place to place. In the hills north of Live Oak Canyon, San Timoteo strata pass upward into reddish colored 
deposits we refer to Qvoa, and the contact interval is easily distinguished by the color contrast between yellowish-gray and reddish sediment. Elsewhere in the map area, yellowishbrown deposits of the San Timoteo Formation are overlain by deposits of unit Qoa1 that are lithologically similar, and in these areas the contact between $S$ an Timoteo beds and overlying units is transitional and not so easily distinguished.

Tgr GRANODIORITE (Tertiary?). Granodioritic quartz porphyry occurring as sills and small bodies intrusive into Pelona Schist. North of Mill Creek the unit is texturally massive to foliated, medium to coarsely crystalline granodiorite that occurs as a small stock-like mass containing xenoliths of biotite-bearing Pelona Schist. South of Mill Creek, units mapped as Tgr consist of intimately intermingled Pelona Schist and igneous rock in which the igneous rocks are the dominant lithology. There, the rock is light yellowish brown and pale yellowish brown to light gray well foliated semischist and lenticular, white to light-gray, finely crystalline quartz porphyry. The intrusive rocks are fine to medium crystalline, but original igneous fabric largely has been obscured by shearing and recrystallization.

Ta ANDESITE TO DACITE (Tertiary?). Dikes of black to very dark gray and very dark grayish brown, finely crystalline to aphanitic, texturally massive porphyritic andesite to dacite having phenocrysts of plagioclase, quartz, and biotite

ps 1 PELONA SCHIST (Mesozoic protolith). Light- to medium-gray, strongly foliated to laminated, quartzofeldspathic sericitic schist containing lenses and pegmatitic segregations of white vein quartz. Rocks locally are biotite-bearing, suggesting contact metamorphism in vicinity of dikes and bodies of $\mathrm{Tg}$. Locally includes finely crystalline bluish gray to greenish gray phyllite that may be metagreenstone.

Mzmg MYLONITIC AND CATACLASTIC GRANITOID ROCK (Mesozoic). Fine to coarsely crystalline granodiorite, tonalite, and quartz diorite that has a variety of non-penetrative and penetrative fabrics, including sheared and crushed rock, brittle cataclastic fabrics (grain crushing and fracturing), and ductile mylonitic fabrics (milling, fluction structure). Locally includes small hornblende-bearing monzogranitic bodies of the Triassic Mount Lowe intrusion as described in the San Gabriel Mountains (see Ehlig, 1981, Joseph and others, 1982, and Barth and Ehlig, 1988). Separated from underlying Pelona Schist by thrust fault correlated with Vincent thrust of eastern San Gabriel Mountains.

\section{Mzfg FOLIATED GRANITOID ROCK} (Mesozoic). Fine to coarsely crystalline leucocratic granitoid rocks having heterogeneous compositions and textures. Some rocks are biotite-bearing with minor hornblende in irregular clots or streaked out aggregates; other rocks are hornblendebearing and biotite poor. Compositions appear to be mainly granodioritic to tonalitic, but locally include monzogranite and quartz diorite.

Mzd DIORITE (Mesozoic). Medium to coarsely crystalline texturally massive to slightly foliated homblende-biotite diorite and quartz diorite. Sequencing relations with Mzmg uncertain.

\section{A CKNOWIEDGMENTS}

This study was conducted in cooperation with the U.S. Army Corps of Engineers. The report benefitted from a technical review by R.F. Yerkes. We thank Peter M. Sadler and Michael O. Woodburne for discussions of the stratigraphy and structure of rocks in the Yucaipa Quadrangle

\section{REFERERCESＣRP區D}

Aydin, A., and Page, B.A., 1984, Diverse Pliocene-Quaternary tectonics in a transform environment, San Francisco Bay region, California: Geological Society of America Bulletin, v. 95, p. 1303-1317.

Barrows, A.G., Kahle, J.E., and Beeby, D.J., 1985, Earthquake hazards and tectonic history of the San Andreas fault zone, Los Angeles County, California: California Division of Mines and Geology Open-File Report 85-10LA, 139 p., scale 1:12,000.

Barrows, A.G., Kahle, J.E., and Beeby, D.J., 1987, Earthquake hazards and tectonic history of the San Andreas fault zone, Los Angeles County, California, in Hester, R.L., and Hallinger, D.E., eds., San Andreas faultCajon Pass to Palmdale: Pacific Section, American Association of Petroleum Geologists, Volume and guidebook no. 59, p. 1-92.

Barth, A.P., and Ehlig, P.L., 1988, Geochemistry and petrogenesis of the marginal zone of the Mount Lowe Intrusion, central San Gabriel Mountains, California: Contributions to Mineralogy and Petrology, v. 100 , p. 192-204.

Christie-Blick, N., and Biddle, K.T., 1985, Deformation and basin formation along strike-slip faults, in Biddle, K.T. and Christie-Blick, N., eds., Strike-slip deformation, basin formation, and sedimentation: Society of Economic Paleontologists and Mineralogists Special Publication 37, p. 1-34.

Crowell, J.C., 1962, Displacement along the San Andreas fault, California: Geological Society of America Special Paper 71, 61 p.

Demirer, Ali, 1985, The Mill Creek Formation--a strike-slip basin filling in the San Andreas fault zone, San Bernardino County, California: Riverside, University of California, M.S. Thesis, $108 \mathrm{p}$.

Dibblee, T.W., Jr., 1964, Geologic map of the San Gorgonio Mountain quadrangle, San Bernardino and Riverside Counties, California: U.S. Geological Survey Miscellaneous Geologic Investigations Map I-431, scale $1: 62,500$.

-.-1968, Displacements on San Andreas fault system in San Gabriel, San Bernardino, and San Jacinto Mountains, southern California, in Dickinson, W.R., and 
Grantz, Arthur, eds., Proceedings of conference on geologic problems of San Andreas fault system: Stanford University Publications in Geological Sciences, v. XI, p. 269-278.

-.--1975, Late Quatemary uplift of the San Bernardino Mountains on the San Andreas and related faults, in Crowell, J.C., ed., San Andreas fault in southern California: California Division of Mines and Geology Special Report 118, p. 127-135.

-..-1982, Geology of the San Bernardino Mountains, southem California, in Fife, D.L., and Minch, J.A., eds., Geology and mineral wealth of the California Transverse Ranges: South Coast Geological Society Guidebook no. 10 (Mason Hill volume), p. 148-169.

Ehlig, P.L., 1968, Causes of distribution of Pelona, Rand, and Orocopia Schist along the San Andreas and Garlock faults, in Dickinson, W.R., and Grantz, Arthur, eds., Proceedings of conference on geologic problems of San Andreas fault system: Stanford University Publications in Geological Sciences, v. XI, p. 294 305.

----1981, Origin and tectonic history of the basement terrane of the San Gabriel Mountains, central Transverse Ranges, in Ernst, W.G., ed., The geotectonic development of California (Rubey Volume I): Englewood Cliffs, New Jersey, Prentice-Hall, Inc., p. 253-283.

----1982, The Vincent thrust: its nature, paleogeographic reconstruction across the San Andreas fault, and bearing on the evolution of the Tranverse Ranges, in Fife, D.L., and Minch, J.A., eds., Geology and mineral wealth of the Califomia Transverse Ranges: South Coast Geological Society Guidebook no. 10 (Mason Hill volume), p. 370-379.

Farley, Thomas, 1979, Geology of a part of northern San Gorgonio Pass, California: Los Angeles, California State University, unpublished M.S. thesis, $159 \mathrm{p}$.

Frick, C., 1921, Extinct vertebrate faunas of the Badlands of Bautista Creek and San Timeteo Canon, southern California: Berkley, University of California Publications in Geology, v. 12, no. 5, p. 277-424.

Friedman, G.M., and Sanders, J.E., 1978, Principles of sedimentology: New York, John Wiley \& Sons, 792 p.

Frizzell, V.A., Jr., Mattinson, J.M., and Matti, J.C., 1986, Distinctive Triassic megaporphyritic monzogranite: evidence for only $160 \mathrm{~km}$ offset along the San Andreas fault, southern Califomia: Journal of Geophysical Research, v. 91, no. B14, p. 14080 14088 .

Gibson, R.C., 1964, Geology of a portion of the Mill Creek area, San Bernardino County, California: Riverside, University of California, M.S. thesis, $50 \mathrm{p}$.

-.--1971, Nonmarine turbidites and the San Andreas fault, San Bernardino Mountains, California, in Elders, W.A., ed., Geological excursions in southern California: Riverside, University of California Campus Museum Contributions, no. 1 , p. 167-181.

Harden, J.W., and Matti, J.C., 1989, Holocene and late Pleistocene slip rates on the San Andreas fault in Yucaipa, California, using displaced alluvial-fan deposits and soil chronology: Geological Society of America Bulletin, v. 101, p. 1107-1117.

Hillenbrand, J. M., 1990, The Potato Sandstone between the Santa Ana River and Badger Canyon, San Bernardino County, southern California: implications for displacement in the San Andreas fault zone: Riverside, University of California, unpublished M.S thesis, $163 \mathrm{p}$.

Jones, L.M., 1988, Focal mechanisms and the state of stress on the San Andreas fault in southern California: Journal of Geophysical Research, v. 93, no. B8, p. 8869-8891.

Joseph, S.E., Criscione, J.J., Davis, T.E., and Ehlig, P.L., 1982, The Lowe igneous pluton, in Fife, D.L., and Minch, J.A., eds., Geology and mineral wealth of the California Tranverse Ranges: South Coast Geological Society Guidebook no. 10 (Mason Hill volume), p. 307-309.

Green, S.M., 1983, Seismotectonic study of the San Andreas, Mission Creek, and Banning fault system: Los Angeles, University of California, unpublished M.S. thesis, $52 \mathrm{p}$.

Matti, J.C., Cox, B.F., and Iverson, S.R., 1983, Mineral resource potential map of the Raywood Flat Roadless Area, San Bernardino and Riverside Counties, California: U.S. Geological Survey Miscellaneous Field Studies Map MF-1563-A, scale 1:62,500.

Matti, J.C., Morton, D.M. and Cox, B.F., 1985, Distribution and geologic relations of fault systems in the vicinity of the central Transverse Ranges, southern California: U.S. Geological Survey Open-File Report 85-365, 27 p., scale 1:250,000.

-1992, The San Andreas fault system in the vicinity of the central Transverse Ranges province, southern California: U.S. Geological Survey Open-File Report 85-365, 27 p., scale 1:250,000.

McFadden, L.D., 1982, The impacts of temporal and spatial climatic changes on alluvial soils genesis in southern California: Tucson, University of Arizona, Ph.D. thesis, 430 p.

McFadden, L.D., and Weldon, R.J., 1987, Rates and processes of soil development on Quatemary terraces in Cajon Pass, California: Geological Society of America Bulletin, v. 98 , p. $280-293$

Miller, C.F., 1977, Early alkalic plutonism in the calc-alkaline batholithic belt of California: Geology, v. 5, p. 685-688. 
Miller, C.F., 1978, An early Mesozoic alkalic magmatic belt in western North America, in Howell, D.G., and McDougall, K.A., eds., Mesozoic paleogeography of the western United States: Pacific Section, Society of Economic Paleontologists and Mineralogists, p. 163-173.

Morton, D.M., 1975, Synopsis of the geology of the eastern San Gabriel Mountains, southern California, in Crowell, J.C., ed., San Andreas fault in southern California: California Division of Mines and Geology Special Report 118, p. 170-176.

-.-1978, Geologic map of the Redlands 7.5' quadrangle, California: U.S. Geological Survey Open-File Report 78-21, scale 1:24,0OO.

Morton, D.M., and Matti, J.C., 1987, The Cucamonga fault zone: Geologic setting and Quaternary history, in Morton, D.M., and Yerkes R.F., eds., Recent reverse faulting in the Transverse Ranges, California: U.S. Geological Survey Professional Paper 1339, p. 179 203.

Morton, D.M., and Miller, F.K., 1975, Geology of the San Andreas fault zone north of San Bernardino between Cajon Canyon and Santa Ana Wash, in Crowell, J.C., ed., San Andreas fault in southern California: California Division of Mines and Geology Special Report 118, p. 136-146.

Munsell Color, 1975, Munsell soil color charts, 1975 edition: Baltimore, Maryland, Macbeth Division of Kollmorgen Corporation

Nicholson, Craig, Seeber, Leonardo, Williams, Patrick, and Sykes, L.R., 1986, Seismicity and fault kinematics through the eastern Transverse Ranges, California: block rotation, strike-slip faulting and low-angle thrusts: Journal of Geophysical Research, v. 91, no. B5, p. 4891-4908.

Owens, G.V., 1959, Sedimentary rocks of lower Mill Creek, San Bernardino Mountains, California: Pomona, Pomona College, M.S. thesis,111 p.

Rasmussen, G.S., and Associates, 1978, Engineering geology investigation tentative Tract 9209, Lots 1-337, San Bernardino County, California: consulting report on file with San Bernardino County Planning Department, $29 \mathrm{p}$.

Rogers, T.H., 1967, San Bernardino sheet of Geologic map of California: California Division of Mines and Geology, scale 1:250,000.

Sadler, P.M., and Demirer, Ali, 1986, Geology of upper Mill Creek and Santa Ana Canyon, southern San Bernardino Mountains, California, field trip 12 of Ehlig, P.L., compiler, Neotectonics and faulting in southern California: Geological Society of America, Cordilleran
Section, 82nd Annual Meeting, Los Angeles, California, 1986, Guidebook and Volume, p. 129-140.

Smith, R.E., 1959, Geology of the Mill Creek area, San Bernardino County, California: Los Angeles, University of California, M.S. thesis, $95 \mathrm{p}$.

Streckeisen A., 1976, To each plutonic rock its proper name: Earth Science reviews, v. 12, p. 1-33.

Sylvester, A.G., 1988, Strike-slip faults: Geological Society of America Bulletin, v. 100, no. 11, p. 1666-1703.

Vaughan, F.E., 1922, Geology of the San Bernardino Mountains north of San Gorgonio Pass: California University Publications in Geological Sciences, v. 13, p. $319-411$.

Weldon, R.J., II, and Sieh, K.E., 1985, Holocene rate of slip and tentative recurrence interval for large earthquakes on the San Andreas fault, Cajon Pass, southern California: Geological Society of America Bulletin, v. 96, p. $793-812$.

West, D.L. 1987, Geology of the Wilson Creek-Mill Creek fault zone--the north flank of the former Mill Creek basin, San Bernardino County, California: Riverside, University of California, unpublished M.S. thesis, $94 \mathrm{p}$.

Woodburne, M.O., 1975, Cenozoic stratigraphy of the Transverse Ranges and adjacent areas, southern California: Geological Society of America Special Paper 162, $91 \mathrm{p}$.

Woodruff, G.A., and Brock, W.Z., 1980, Soil survey of San Bernardino County, southwestern part, California: U.S. Department of Agriculture, Soil Conservation Service, 64 p., scale 1:24,000. 